Utah State University

DigitalCommons@USU

\title{
Estimation of Surface Thermal Emissivity in a Vineyard for UAV Microbolometer Thermal Cameras Using NASA HyTES Hyperspectral Thermal, and Landsat and AggieAir Optical Data
}

\author{
Alfonso F. Torres-Rua \\ Utah State University, alfonso.torres@usu.edu \\ Mahyar Aboutalebi \\ Utah State University, mahyar.aboutalebi@gmail.com \\ Timothy Wright \\ Antorcha LLC \\ Ayman Nassar \\ Utah State University, aymnassar@gmail.com \\ Pierre Guillevic \\ Ephlluetstaisołndardpditignal works at: https://digitalcommons.usu.edu/aggieair_pubs \\ Lawrence the Avipiation Commons \\ Utah State University, lawrence.hipps@usu.edu
}

\section{Recommended Citation}

Slfonso Torres-Rua, Mahyar,Aboutalebi, Timothy Wright, Ayman Nassar, Pierre Guillevic, Lawrence Hipps, Feng Gao, Kevin Jim, Maria Mar Alsina, Calvin Coopmans, Mac McKee, and William Kustas "Estimation of surface thermal emissivity in a vineyard for UAV microbolometer thermal cameras using NASA HyTES hyperspectral thermal, and landsat and AggieAir optical data", Proc. SPIE 11008, Autonomous Air and Ground Sensing Systems for Agricultural Optimization and Phenotyping IV, 1100802 (14 May 2019); http://dx.doi.org/10.1117/12.2518958

This Conference Paper is brought to you for free and open access by the AggieAir at DigitalCommons@USU. It has been accepted for inclusion in AggieAir Publications by an authorized administrator of DigitalCommons@USU. For more information, please contact digitalcommons@usu.edu.

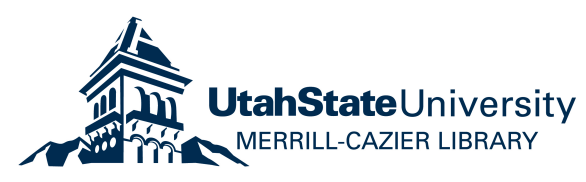




\section{Authors}

Alfonso F. Torres-Rua, Mahyar Aboutalebi, Timothy Wright, Ayman Nassar, Pierre Guillevic, Lawrence Hipps, Feng Gao, Kevin Jim, Maria Mar Alsina, Calvin Coopmans, Mac McKee, and William Kustas 


\section{Estimation of surface thermal emissivity in a vineyard for UAV microbolometer thermal cameras using NASA HyTES hyperspectral thermal, and landsat and AggieAir optical data}

Alfonso Torres-Rua, Mahyar Aboutalebi, Timothy Wright, Ayman Nassar, Pierre Guillevic, et al.

Alfonso Torres-Rua, Mahyar Aboutalebi, Timothy Wright, Ayman Nassar, Pierre Guillevic, Lawrence Hipps, Feng Gao, Kevin Jim, Maria Mar Alsina, Calvin Coopmans, Mac McKee, William Kustas, "Estimation of surface thermal emissivity in a vineyard for UAV microbolometer thermal cameras using NASA HyTES hyperspectral thermal, and landsat and AggieAir optical data," Proc. SPIE 11008, Autonomous Air and Ground Sensing Systems for Agricultural Optimization and Phenotyping IV, 1100802 (14 May 2019); doi: 10.1117/12.2518958

Event: SPIE Defense + Commercial Sensing, 2019, Baltimore, Maryland, United States 


\title{
Estimation of surface thermal emissivity in a vineyard for UAV microbolometer thermal cameras using NASA HyTES hyperspectral thermal, Landsat and AggieAir optical data
}

\author{
Alfonso Torres-Rua*1, Mahyar Aboutalebi ${ }^{1}$, Timothy Wright ${ }^{2}$, Ayman Nassar $^{1}$, Pierre Guillevic $^{3}$, \\ Lawrence Hipps ${ }^{2}$, Feng Gao ${ }^{4}$, Kevin $\mathrm{Jim}^{5}$, Maria Mar Alsina ${ }^{6}$, Calvin Coopmans ${ }^{7}$, Mac McKee ${ }^{1}$, \\ William Kustas 4 \\ 1 Utah State University, Civil and Env Engineering, Old Main Hill, Logan, Utah 84322, USA \\ 2 Utah State University, College of Agriculture, Old Main Hill, Logan, Utah 84322, USA \\ 3 University of Maryland, Department of Geographical Sciences, College Park, MD 20740, USA \\ 4 USDA-ARS Hydrology and Remote Sensing Laboratory, Beltsville, MD 20705 USA \\ 5 OceanIT, 828 Fort Street Mall, Suite 600, Honolulu, Hawaii 96813 \\ 6 E\&J Gallo, 600 Yosemite Blvd, Modesto, CA 95354 \\ 7 Utah State University, Electrical Engineering, Old Main Hill, Logan, Utah 84322, USA
}

\begin{abstract}
Microbolometer thermal cameras in UAVs and manned aircraft allow for the acquisition of highresolution temperature data, which, along with optical reflectance, contributes to monitoring and modeling of agricultural and natural environments. Furthermore, these temperature measurements have facilitated the development of advanced models of crop water stress and evapotranspiration in precision agriculture and heat fluxes exchanges in small river streams and corridors. Microbolometer cameras capture thermal information at blackbody or radiometric settings (narrowband emissivity equates to unity). While it is customary that the modeler uses assumed emissivity values (e.g. 0.990.96 for agricultural and environmental settings); some applications (e.g. Vegetation Health Index), and complex models such as energy balance-based models (e.g. evapotranspiration) could benefit from spatial estimates of surface emissivity for true or kinetic temperature mapping. In that regard, this work presents an analysis of the spectral characteristics of a microbolometer camera with regard to emissivity, along with a methodology to infer thermal emissivity spatially based on the spectral
\end{abstract}

\footnotetext{
1* alfonso.torres@usu.edu; phone 1435797 0397; fax 1435 797-3663; uwrl.usu.edu
} 
characteristics of the microbolometer camera. For this work, the MODIS UCBS Emissivity Library, NASA HyTES hyperspectral emissivity, Landsat, and Utah State University AggieAir UAV surface reflectance products are employed. The methodology is applied to a commercial vineyard agricultural setting located in Lodi, California, where HyTES, Landsat, and AggieAir UAV spatial data were collected in the 2014 growing season. Assessment of the microbolometer spectral response with regards to emissivity and emissivity modeling performance for the area of study are presented and discussed.

Keywords: Thermal emissivity, land surface temperature, UAV, microbolometer camera, NASA HYTES, MODIS Emissivity, Landsat

\section{INTRODUCTION}

A major goal of thermal remote sensing is the estimation of the true (kinetic) surface temperature due to its usefulness in diverse applications such as modeling energy balance ${ }^{1-6}$, vegetation conditions ${ }^{7,8}$, environmental stressors effects, and climate change ${ }^{9-11}$. The importance of thermal remote sensing in agriculture has been demonstrated at scales from global to regional and from farm to sub-plant, the latter scale being addressed by infrared temperature sensors ${ }^{12}$ and microbolometer cameras ${ }^{13,14}$. Infrared sensors and microbolometer cameras differ from the technologies used in satellite missions. The main difference is the lack of "cooling" mechanisms to maintain the sensor at a constant operating temperature. Microbolometer cameras require additional procedures to stabilize the operation conditions before and during use, thus avoiding "drift" conditions that are difficult to correct/adjust after data collection ${ }^{15-17}$. Furthermore, infrared sensors and microbolometer cameras have, by design, different spectral characteristics ${ }^{18-20}$, making them distinct from the spectral characteristics from scientific satellite missions (Landsat, MODIS, ASTER, ECOSTRESS) ${ }^{21-25}$ as seen in Figure 1. 


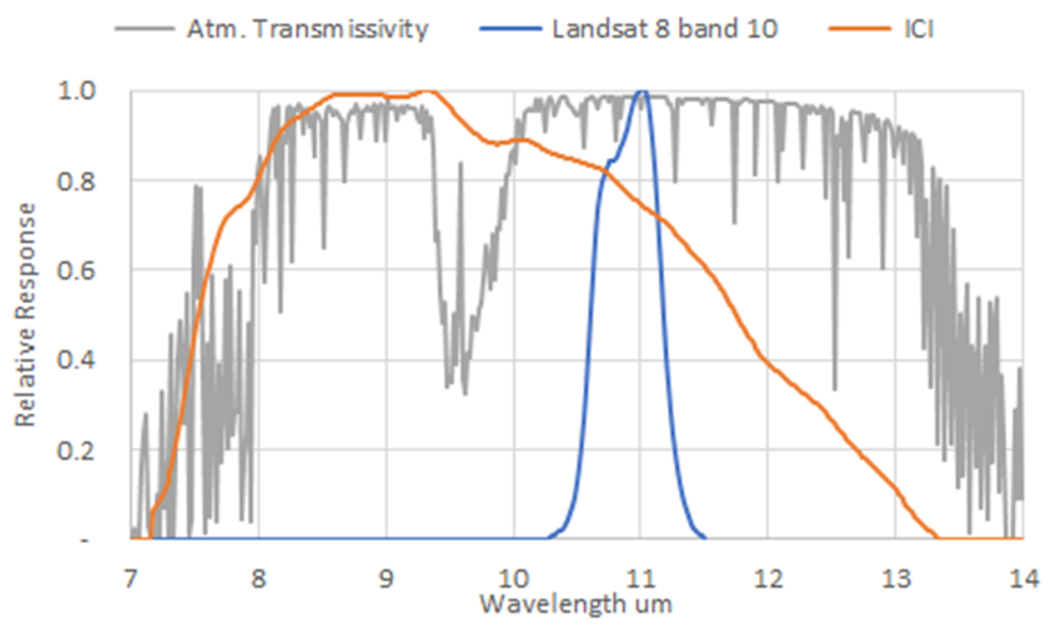

Figure 1. Spectral Response of the average Atmospheric Transmissivity, Landsat 8 Band 10 and ICI 9640-P26 Microbolometer Camera Relative Spectral Response in the 7 to 14 um region. Notice the spectral width of Landsat Band 10 vs ICI.

As shown in Fig.1, due to its spectral response, any microbolometer camera will be affected by the reduction in atmospheric transmissivity at the beginning and end of the spectral thermal windows and, additionally, by the significant atmospheric absorption due to Ozone molecules ("dip" in atmospheric transmissivity between 9 and 10 um). Furthermore, Landsat and other scientific thermal satellites choose a narrow spectral width to avoid a reduction in thermal signal due to atmospheric transmissivity. Microbolometer sensors technology rely on the width of the thermal spectral window to capture an adequate number of photons for thermal measurements. Therefore, it is expected that the spectral response of microbolometer cameras will affect kinematic temperature estimation procedures and prompting for methodologies to make them equivalent to satellite thermal products.

Regarding kinematic and sensor (blackbody) temperature, the spectral response of the thermal sensor is vital towards the estimation of the true (or Kinematic) surface temperature. The relationship between radiometric and the kinematic temperature can be approximated as shown here 27,28 :

$$
\mathrm{T}_{\mathrm{rad}}=\varepsilon^{1 / 4} \mathrm{~T}_{\text {kin }}
$$

There $\mathrm{T}_{\mathrm{rad}}$ is the radiometric temperature (Kelvin) measured by the temperature sensor (Landsat or microbolometer), $T_{k i n}$ is the surface or kinematic temperature (Kelvin) and $\varepsilon$ is the thermal emissivity of the surface being measured. This emissivity is also called narrowband emissivity, due to its 
relationship to the spectral characteristics of the sensor measuring $\mathrm{T}_{\text {rad. }}$ This equation can be considered valid only for very small distances between the sensor and the surface ( 1 to $\sim 3 \mathrm{~m})$. A complete solution of the atmospheric transmissivity is required for longer distances (which includes UAVs, aircraft, and satellites) and is described in several publications ${ }^{13,29-32}$.

Thermal emissivity is a property of every surface and is influenced by the characteristics of the surface, such as spectral response, reflectance, roughness, thickness, water content, and energy amount (kinetic energy). Emissivity is typically reported in educational literature as an average value within the 8 to $14 \mu \mathrm{m}$ range 27,28 . For satellite temperature applications, a significant effort is made to estimate narrowband emissivity based on the spectral response of the sensor as presented here ${ }^{33-35}$ :

$$
\varepsilon=\int_{\lambda_{1}}^{\lambda_{2}} \varepsilon_{\lambda} \cdot \mathrm{f}_{\lambda} \mathrm{d} \lambda
$$

Where $\varepsilon_{\lambda}$ is the emissivity value for a wavelength $\lambda$, and $\mathrm{f}_{\lambda}$ is the spectral response of the sensor for a specific waveband. The integral of $f_{\lambda}$ is equal to unity, and $\lambda_{1}$ and $\lambda_{2}$ are the limits of the spectral response of the sensor. Details of the derivation of Equation 2 can be found here ${ }^{33}$.

Given the spectral differences between satellite and microbolometer thermal sensors, the objectives of this study are twofold: (1) determine the impact of the spectral response of a microbolometer thermal sensor, (the ICI 9640-P Series radiometric camera ${ }^{26}$ ), on the estimation of narrowband emissivities and surface temperature for agricultural and environmental environments, and (2) develop an initial model for spatially estimating narrowband emissivity that responds to the microbolometer camera characteristics based on optical and infrared information from Landsat / AggieAir UAV sensors.

\section{METHODS}

Relative to the first objective, the University of Notre Dame performed a laboratory test on the ICI 9640-P camera following a published procedure ${ }^{36}$ to derive the lens plus microbolometer sensor spectral response that is presented in Fig. 1. Hyperspectral emissivity information for different agricultural and natural environment surface conditions in the 3 to $14 \mu \mathrm{m}$ range was acquired from the MODIS UCSB Emissivity Library ${ }^{37}$ for assessment of narrowband emissivities for ICI and Landsat. Relative to the second objective, hyperspectral spatial information was retrieved from the NASA JPL 
Hyperspectral Thermal Emission Spectrometer -HYTES airborne Program for multiple commercial agricultural vineyards located in California. These vineyards are part of the Grape Remote sensing Atmospheric Profile \& Evapotranspiration eXperiment GRAPEX ${ }^{38}$. Details of the HYTES sensor and technology can be found here ${ }^{39-42}$ with a list of flown locations up to date here ${ }^{43}$. For the area of study, the spatial emissivity information covered different agricultural lands, (vineyards, alfalfa) and natural environments as presented in Fig. 2.

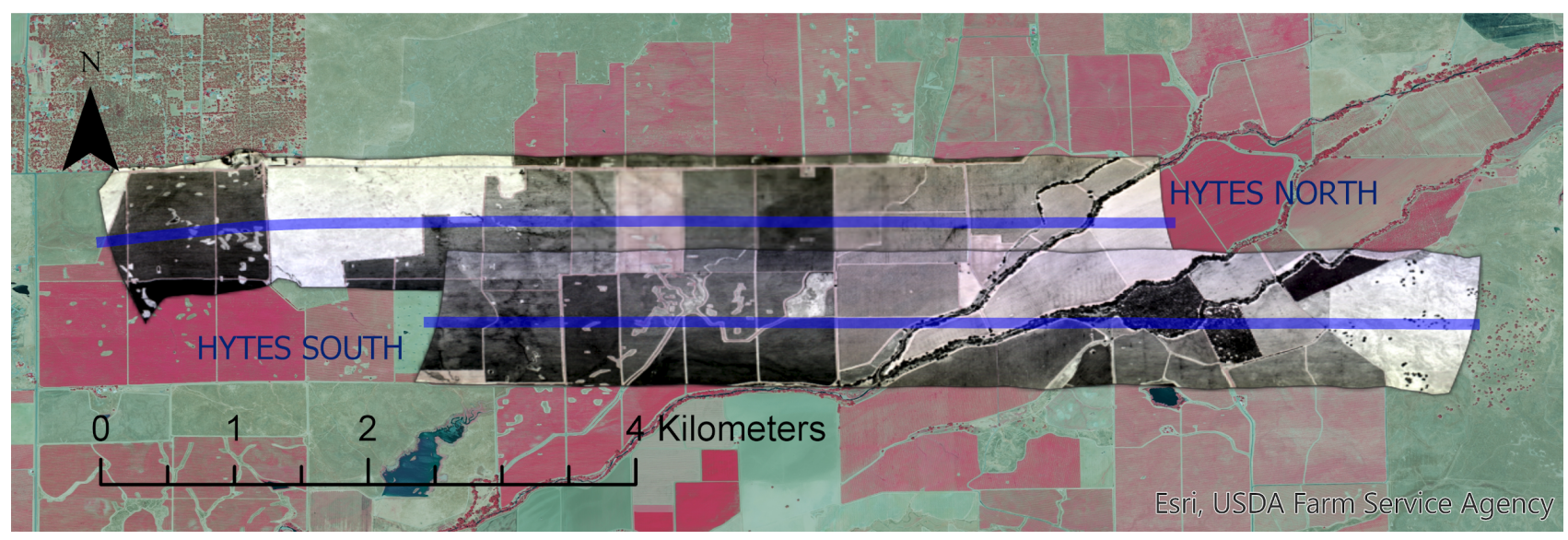

Fig 2. 2014 NASA HYTES bands $150(10.1 \mu \mathrm{m}), 100(9.2 \mu \mathrm{m})$, and $58(8.5 \mu \mathrm{m})$ overpass over multiple vineyards and natural areas near Galt, CA. Two HYTES flights on the same date and time (NORTH and SOUTH, blue lines indicate flights) are included for this study.

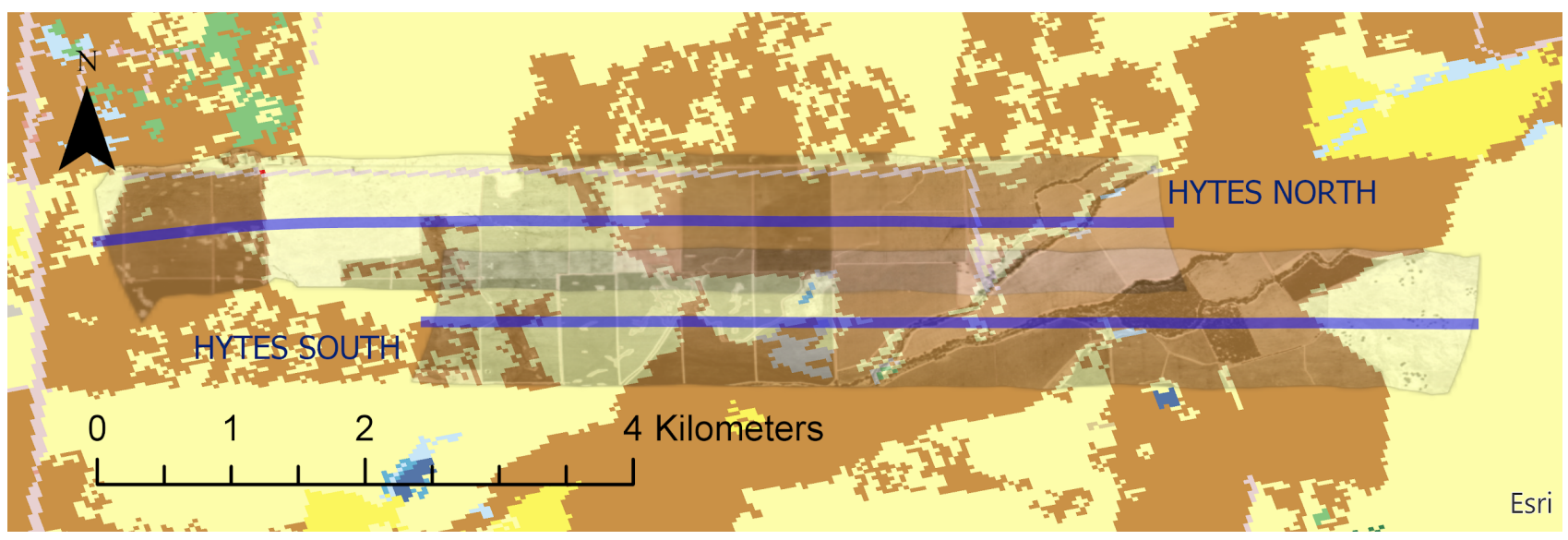

Fig 3. 2014 NASA HYTES bands $150(10.1 \mu \mathrm{m}), 100(9.2 \mu \mathrm{m})$, and $58(8.5 \mu \mathrm{m})$ overpass, along with $2011 \mathrm{National}$ Land Cover Database (NLCD). (Brown color indicates cultivated lands and yellow Grassland/Herbaceous). Note that in several locations 2011 NLCD classes do not correspond to 2014 agricultural development.

Landsat ETM+ Surface Reflectance Product is available from USGS ${ }^{44}$ for the same date as the HYTES airborne flights. In addition, AggieAir optical information was captured in the same growing season at a later date but in conjunction with Landsat 7 overpasses. Details on the thermal sensors' 
characteristics are presented in Table 1. Details on dates and times for HYTES, Landsat, and AggieAir are presented in Table 2.

Table 1: NASA JPL HYTES and ICI 9640-P Characteristics and Products

\begin{tabular}{|l|l|l|}
\hline \multicolumn{1}{|c|}{ INSTRUMENT } & \multicolumn{1}{|c|}{ Spectrometer } & \multicolumn{1}{|c|}{ Thermal Camera } \\
\hline Brand/Model & JLP HYTES & ICI/9640-P \\
\hline Weight (gr) & 12000 & 141 \\
\hline Image Size (pixel) & 512 per track & 640 by 480 \\
\hline Ground Resolution (m) & $\sim 6$ & $\sim 0.6$ \\
\hline Sensor Type & pushbroom & snapshot \\
\hline Spectral Range ( $\mu \mathrm{m})$ & $7.5-12$ & $7-14$ \\
\hline Number of Bands & 256 & 1 \\
\hline Spectral Band Centre $(\mu \mathrm{m})$ & 9.75 & 10.35 \\
\hline Operating Range & N/A & -40 to $140^{\circ} \mathrm{C}$ \\
\hline Reported Accuracy & N/A & $+/-1.0^{\circ} \mathrm{C}$ \\
\hline Reported Emissivity & per band & 1.0 \\
\hline NIST Traceable? & N/A & NOT REPORTED \\
\hline Available product & Hyperspectral Emissivity & \\
\hline
\end{tabular}


Table 2. Spatial Products and Capture Times

\begin{tabular}{|l|l|l|l|}
\hline \multicolumn{1}{|c|}{$\begin{array}{c}\text { Spatial } \\
\text { Product }\end{array}$} & \multicolumn{1}{|c|}{ Spatial Information } & \multicolumn{1}{c|}{$\begin{array}{c}\text { Ground } \\
\text { Resolution (m) }\end{array}$} & $\begin{array}{c}\text { Capture Date and } \\
\text { Time (PST) }\end{array}$ \\
\hline $\begin{array}{l}\text { NASA JPL } \\
\text { HYTES }\end{array}$ & Hyperspectral Emissivity & 6 & $2014-07-0913: 23$ \\
\hline Landsat ETM+ & Surface Corrected Reflectance & 30 & $2014-07-0910: 36$ \\
\hline AggieAir & $\begin{array}{l}\text { High-Resolution Reflectance } \\
\text { and Temperature }\end{array}$ & $\begin{array}{l}0.15 \text { Reflectance } \\
0.60 \text { Temperature }\end{array}$ & $2014-08-0910: 36$ \\
\hline
\end{tabular}

It is evident from Table 2 that a direct comparison of surface temperature between HYTES and NASA $\mathrm{ETM}+$ is not possible due to the time difference ( $\sim 3$ hours), nor is a comparison between AggieAir, HYTES, and Landsat possible due to dates. The proposed procedure for Objective (2) is as follows:

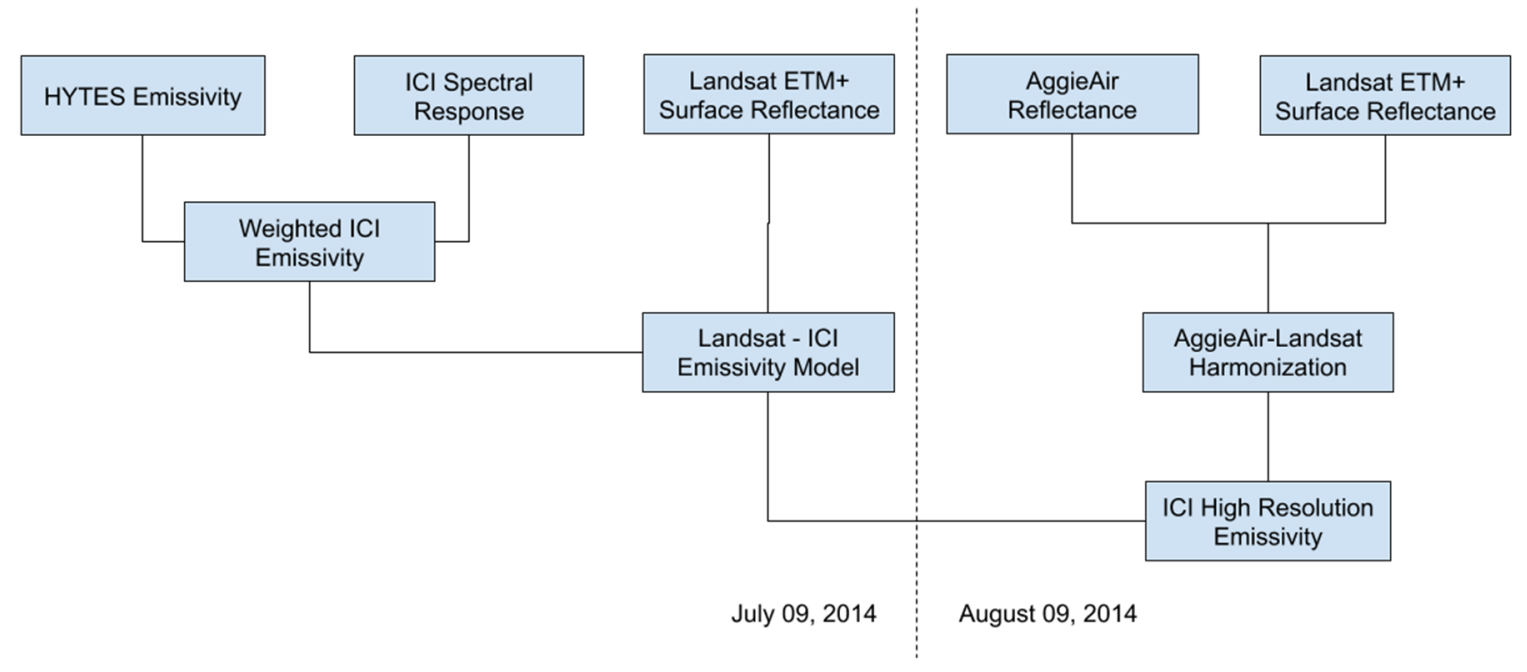

Fig. 4 Flowchart for Estimation of High-Resolution Emissivity for ICI Cameras

The estimation of spatial emissivity using HYTES information tailored to the ICI microbolometer spectral response is based on several steps as shown in Fig.4. The first step is the derivation of an HYTES emissivity product that responds to the ICI spectral response from Eq. 2. The ICI emissivity is then linearly aggregated to Landsat spatial scale for reflectance-emissivity model estimation. On the AggieAir UAV date, UAV reflectance information is "harmonized" to Landsat reflectance 
characteristics based on the work described here ${ }^{45}$ taking advantage of the same data collection timing. Lastly, the reflectance-emissivity model is applied to harmonized AggieAir reflectance for estimation of emissivity at UAV resolution $(0.15 \mathrm{~m})$.

\section{RESULTS}

\subsection{Hyperspectral Emissivity Analysis for Landsat and ICI thermal sensors}

Based on spectral emissivity curves available in the MODIS UCBS Emissivity Library, three major groups are considered for this analysis: water, vegetation, and soil. Not all vegetation nor soil types are available in MODIS UCBS, thus a representative set is analyzed. The emissivity spectral responses for these three major groups, along with Landsat and ICI spectral responses, are presented in Fig. 5. In addition, computation of the Landsat and ICI emissivities using Equation 2 along with emissivity typically reported in the 8-14um spectral range for the evaluated groups are presented in Table 3.

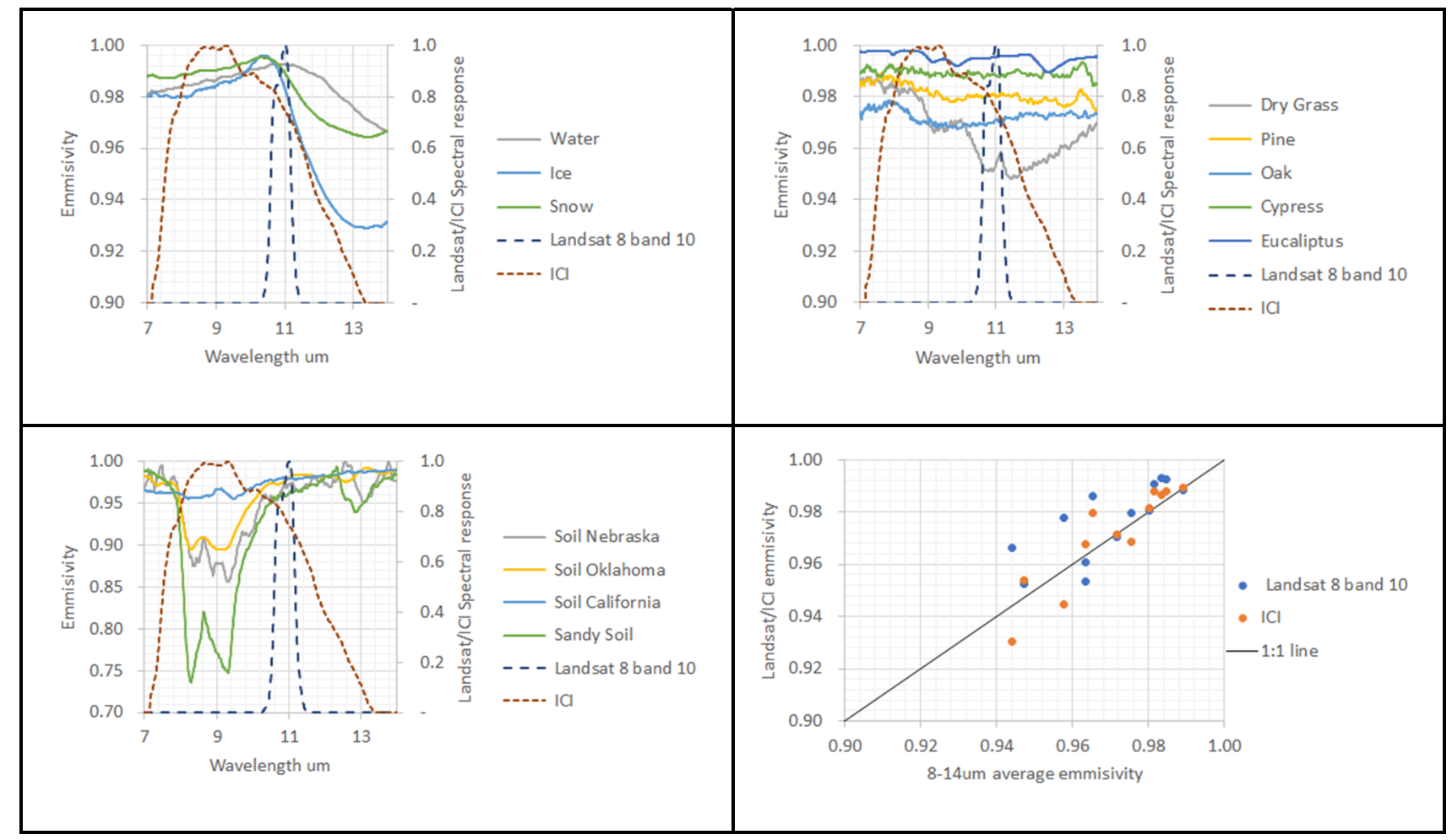

Fig. 5: Emissivity comparison based on MODIS UCBS Emissivity Library, Landsat and ICI spectral response for water surfaces (top left), vegetation (top right), and soil (bottom left), and a comparison of derived emissivities for Landsat and ICI vs reported 8-14um (bottom left). It is evident that emissivity values agree for water, agree less for vegetation but not for soil surfaces. 
Table 3: Summary of emissivity values presented in Fig.5 for 8-14um, Landsat and ICI thermal sensors using MODIS UCBS Emissivity Library.

\begin{tabular}{|c|c|c|c|}
\hline Material & 8-14um & Landsat & ICI \\
\hline Water & 0.98 & 0.99 & 0.99 \\
\hline Ice & 0.97 & 0.99 & 0.98 \\
\hline Snow & 0.98 & 0.99 & 0.99 \\
\hline Soil Nebraska & 0.94 & 0.97 & 0.93 \\
\hline Soil Oklahoma & 0.96 & 0.98 & 0.94 \\
\hline Soil California & 0.98 & 0.98 & 0.97 \\
\hline Sandy Soil & 0.96 & 0.96 & 0.89 \\
\hline Dry Grass & 0.96 & 0.95 & 0.97 \\
\hline Pine & 0.98 & 0.98 & 0.98 \\
\hline Oak & 0.97 & 0.97 & 0.97 \\
\hline Cypress & 0.99 & 0.99 & 0.99 \\
\hline Eucalyptus & 0.95 & 0.95 & 0.95 \\
\hline
\end{tabular}

It is evident that the spectral response of the thermal sensor plays a role in the narrowband emissivity estimates as shown in Fig. 5 and Table 3. Typical 8-14um averages for water surfaces agree with Landsat 8 and ICI sensors, as the differences between emissivity values are small. A similar affirmation can be made for vegetation. Nevertheless, for soil surfaces, the ICI sensor diverges from 8-14um and Landsat emissivities, depending on the soil type present, but it is clear that emissivity for sandy soils will diverge more. This divergence in emissivity for soils and sandy surfaces has been 
documented previously ${ }^{46}$, is due to strong quartz absorption. To further estimate the magnitude of the effects of emissivity for Landsat and ICI sensors, differences between kinetic and sensor temperature from 0 to 70 degrees Celsius for water, vegetation and soil are calculated and presented in Fig. 6.

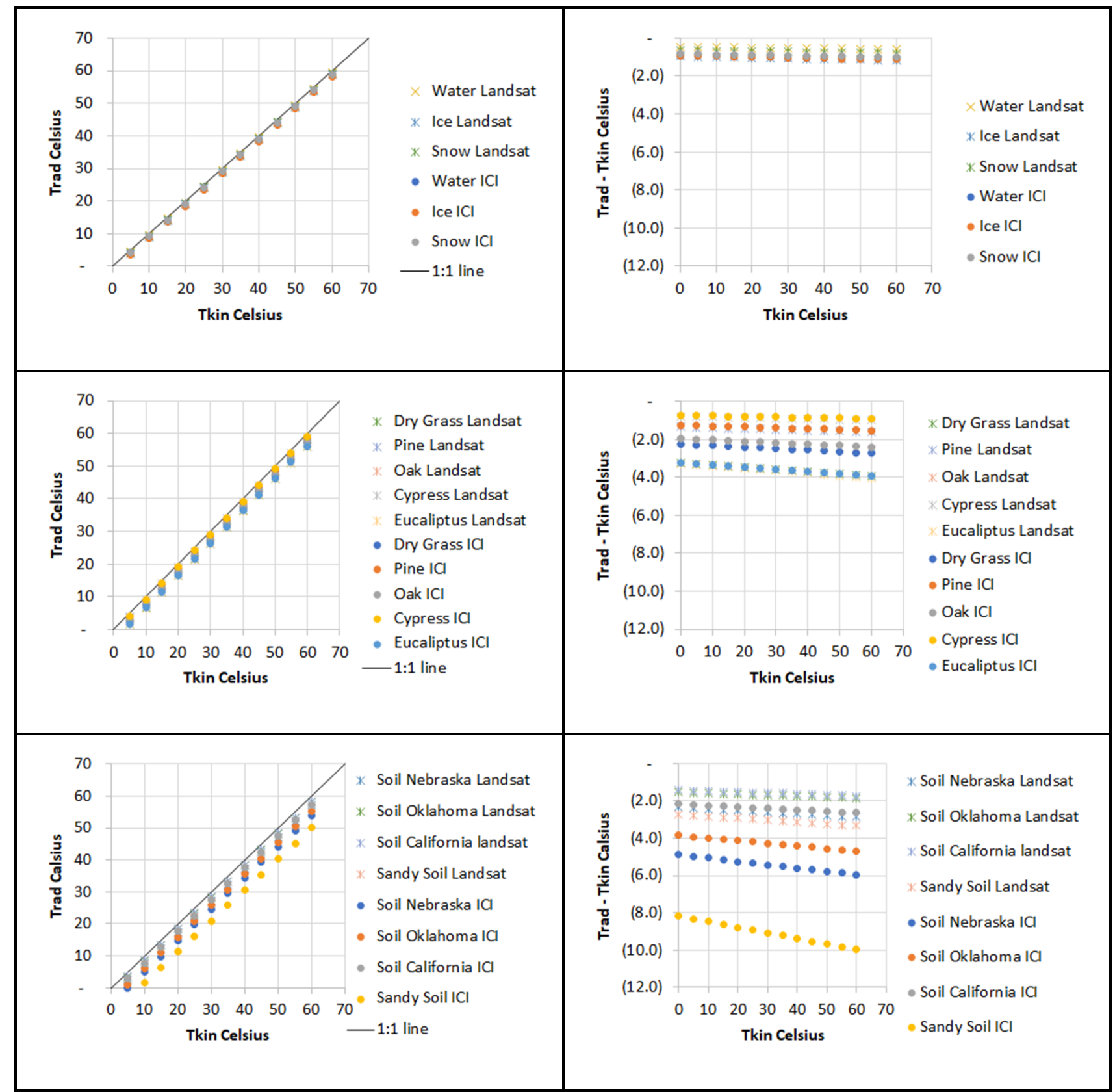

Fig. 6 Kinetic and Radiation Temperatures comparison (left column) and differences (right column) based on Landsat and ICI emissivities for water (top row), vegetation (middle row) and soil (bottom row). Note the agreement of Landsat and ICI for water $(<2$ degrees Celsius), and for vegetation ( $<4$ degrees Celsius). Soil surfaces present a significantly larger difference for ICI than for Landsat. 
The results presented in Fig. 6 for kinematic and radiometric temperatures using Landsat or ICI indicates that the spectral response of the microbolometer camera affects the kinetic temperature estimates of soils to a greater magnitude than for vegetation or water. For Landsat, the expected maximum temperature difference across all evaluated surface groups is up to 4 degrees Celsius. For the ICI camera, the difference can be up to 10 degrees Celsius. This comparison indicates that care must be taken when mapping soil surfaces for energy balance methodologies due to the larger emissivity correction needed when using microbolometer cameras.

\subsection{ICI Emissivity Model}

As described in Section 2 and Figure 4, an HYTES emissivity product that responds to the ICI spectral response derived for the two HYTES flights (North and South) was scaled to Landsat resolution and is presented in Fig. 7.
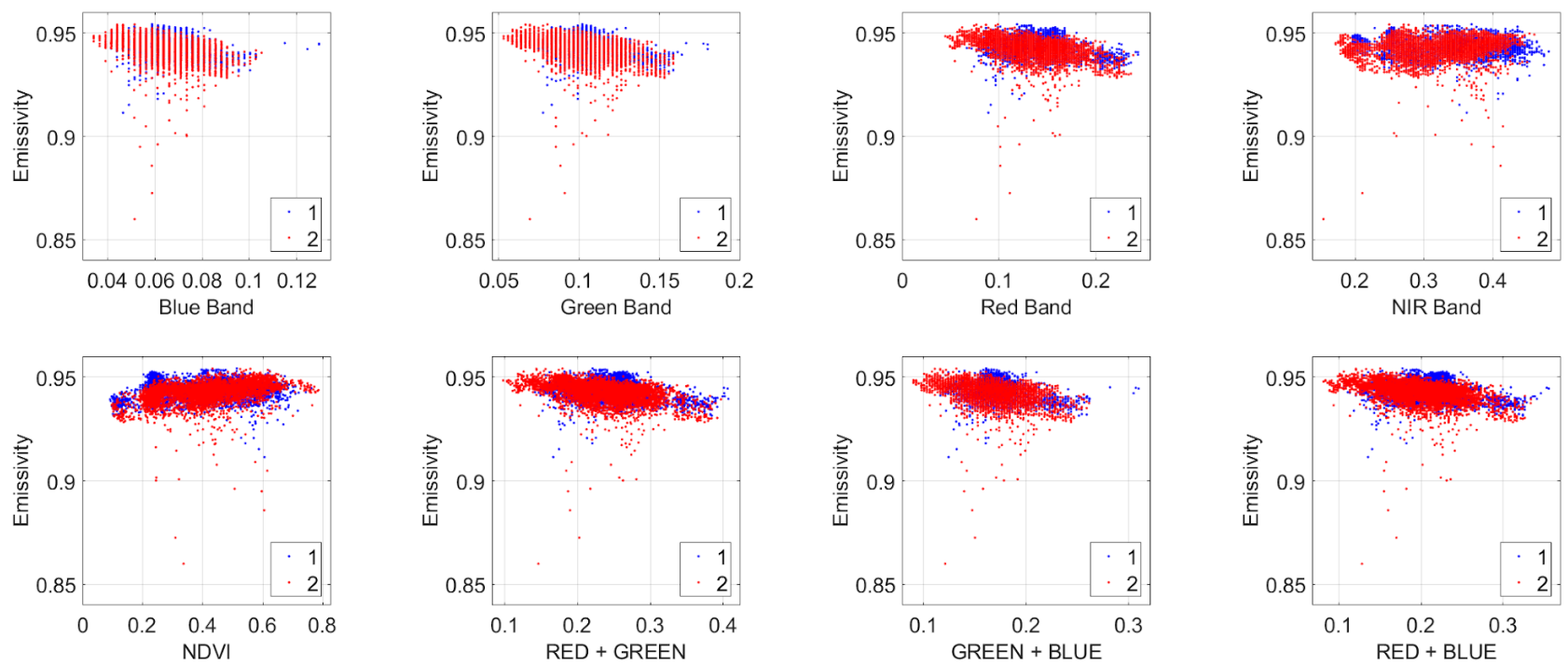

Fig.7 HYTES ICI derived emissivity at Landsat scale vs spectral bands (Blue, Green, Red, and NIR) and band combination from Landsat. SWIR bands are not considered due to lack of an equivalent in AggieAir UAV sensors. Blue and Red scatter color (named 1 and 2) are the HYTES North and South, respectively.

It is evident from the comparison of Landsat optical spectral bands and combinations and HYTES ICI emissivity values in Fig. 7, that the correlation is limited or weak. In every presented scatterplot, a linear trend is clear, but with a considerable variance along the trend, indicating significant limitations for linear modeling of emissivity. Nonetheless, an initial approach that considers a linear combination of spectral bands from Landsat is presented below (Table 4 and Fig. 8). 
Table 4. Performance of a Linear model for ICI emissivity estimation based on Landsat bands

\begin{tabular}{|l|l|l|l|}
\hline Model & Inputs & Coefficients & Fit Statistics \\
\hline $\mathrm{y}=\mathrm{a}+\mathrm{b}^{*} \mathrm{x} 1^{\wedge} 2+\mathrm{c}^{*} \mathrm{x} 2^{\wedge} 2+\mathrm{d}^{*} \mathrm{x} 3^{\wedge} 2+\mathrm{e}^{*} \mathrm{x} 1$ & $\mathrm{x} 1:$ GREEN & $\mathrm{a}: 0.943$ & Obs: 9600 \\
& $\mathrm{x} 2:$ NIR & $\mathrm{b}:-0.615$ & RMSE: 0.004 \\
& $\mathrm{x} 3:$ NDVI & $\mathrm{c}:-0.056$ & \\
& & $\mathrm{~d}:-0.005$ & \\
& $\mathrm{e}: 0.042$ & \\
\hline
\end{tabular}
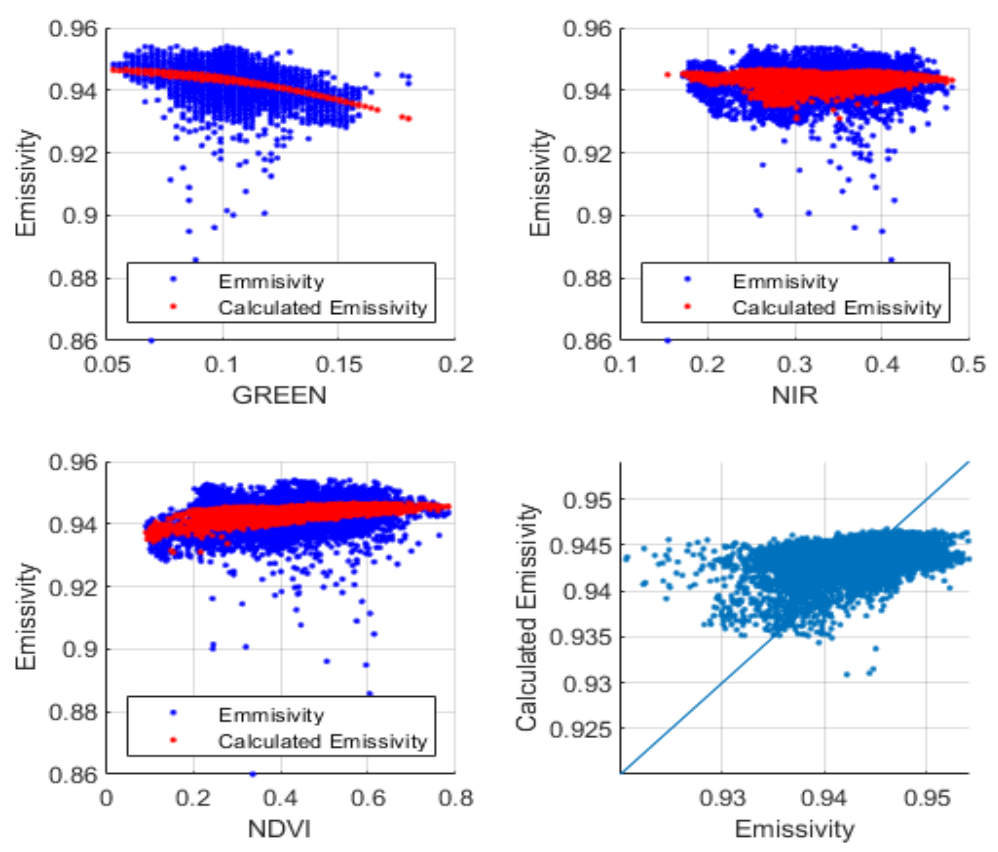

Fig. 8 Performance of a Linear model for ICI emissivity estimation based on Landsat reflectance products.

Table 4 and Fig. 8 show that a linear model based on reflectance and vegetation indices has a limited prediction capability due to the weak linear relationship between Landsat spectral bands and the HYTES ICI emissivity. A second approach, based on machine learning (Regression Decision Tree) ${ }^{47}$ and implemented in MATLAB (function fitrtree) is implemented as shown below: 
Table 5. Performance of a Regression model for ICI emissivity estimation based on Landsat bands

\begin{tabular}{|l|l|l|l|}
\hline Model & Inputs & $\begin{array}{l}\text { Calibration } \\
\text { scheme }\end{array}$ & Fit Statistics \\
\hline Regression Decision Tree & BLUE & $\begin{array}{l}70 \% \text { Training } \\
30 \% \text { Testing }\end{array}$ & $\begin{array}{l}\text { Obs: } 9600 \\
\text { RMSE: } 0.004\end{array}$ \\
& $\begin{array}{l}\text { GEDEN } \\
\text { NIR }\end{array}$ & \\
\hline
\end{tabular}
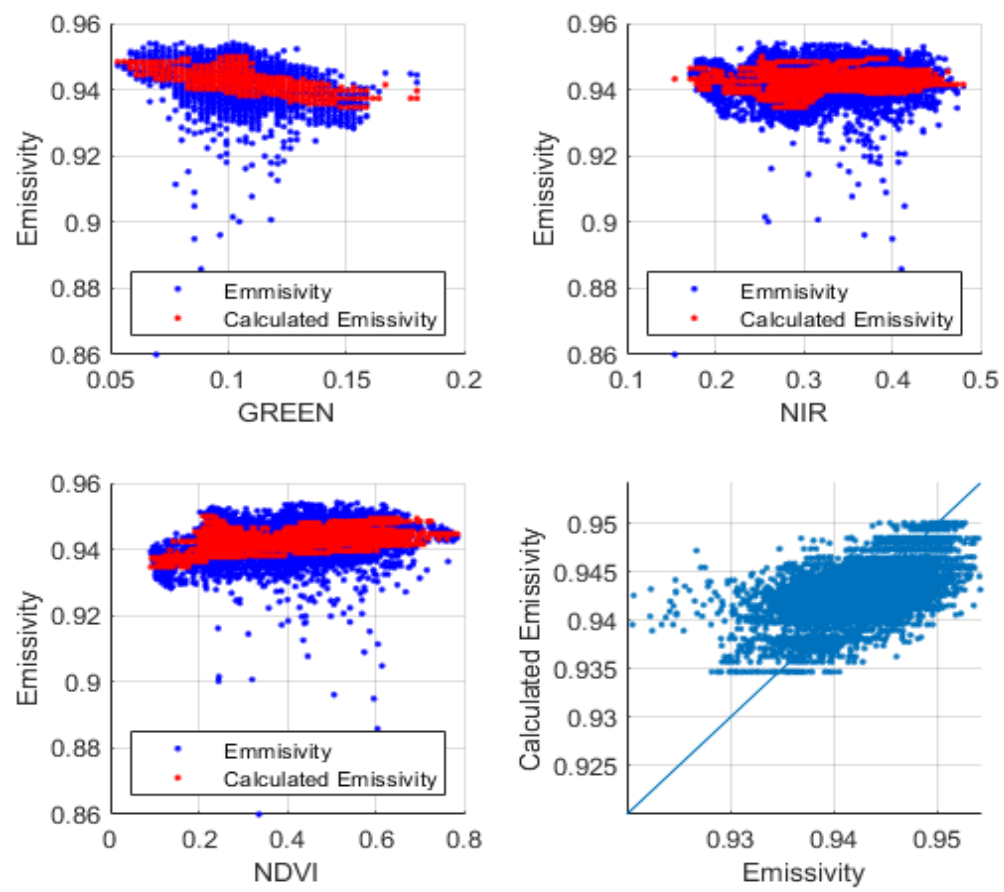

Fig. 9 Performance of a Regression Decision Tree model for ICI emissivity estimation based on Landsat optical bands.

The implemented Regression Decision Tree model provided a more adequate ICI derived emissivity estimation than the linear model. Nevertheless, the 1:1 comparison provided in Fig 8, indicates that the model can benefit from additional efforts in input variables and additional HYTES and Landsat datasets. Figs. 9 and 10 show the derivation of ICI emissivity at $0.15 \mathrm{~m} /$ pixel using the Landsat/AggieAir UAV harmonized reflectance products. 

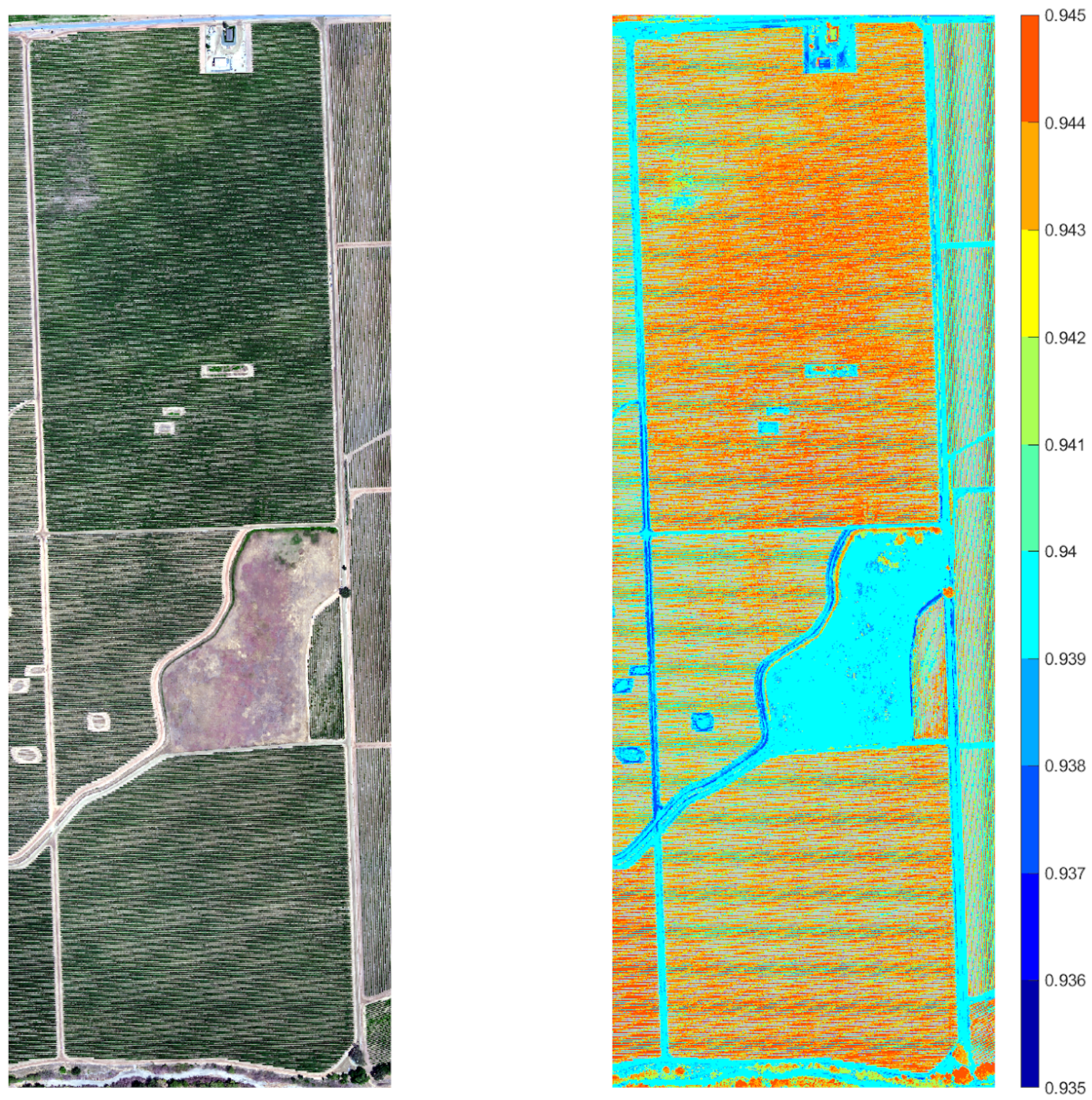

Fig. 10 Estimation of High-resolution ICI emissivity using HYTES -Landsat Regression Decision Tree and AggieAir reflectance. Emissivity values range from 0.935 to 0.945 . The model provides a clear differentiation between bare soil (soil and service roads) and vegetation (vineyards and forest) 

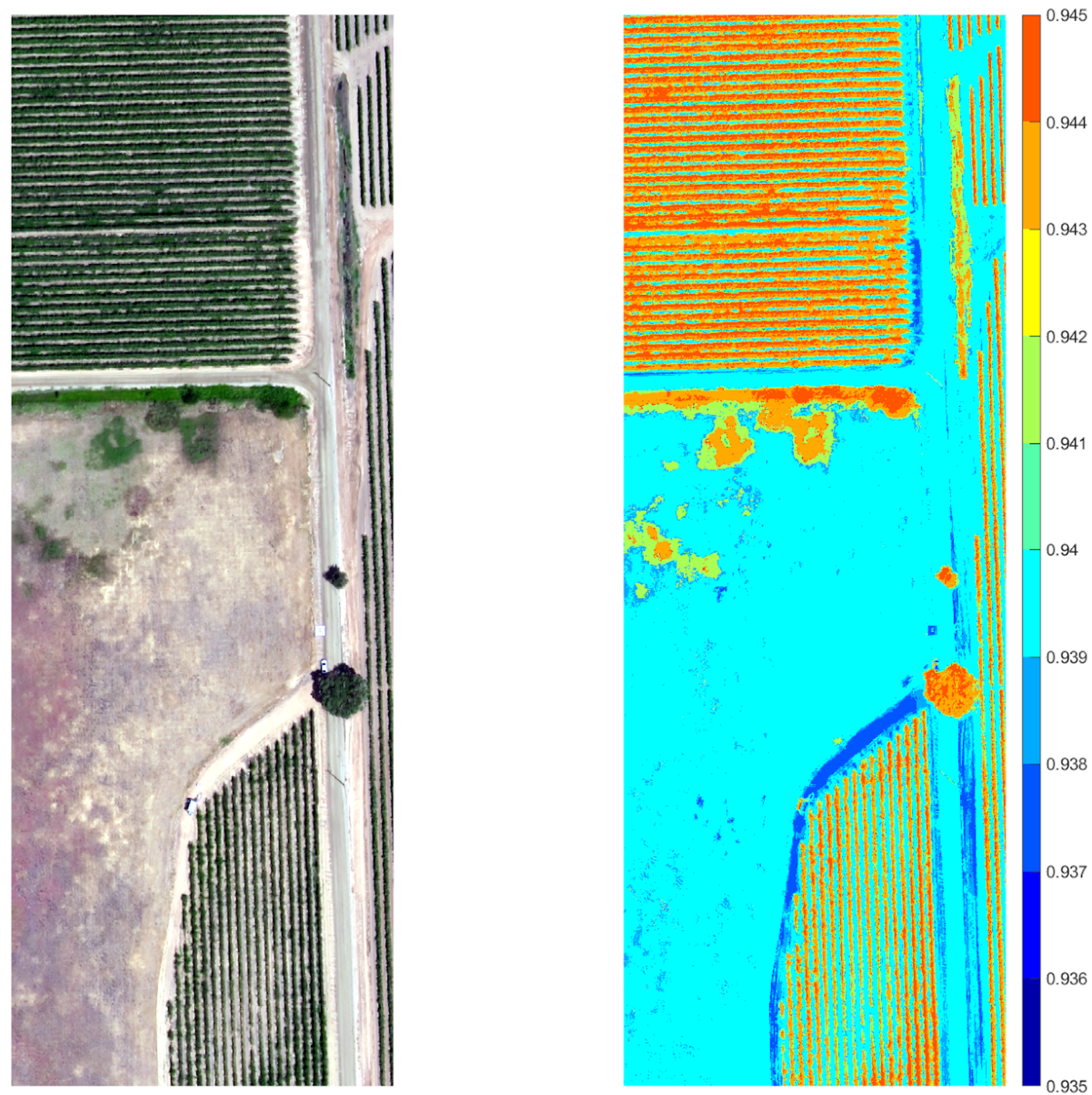

Fig 11: Close Up of Harmonized Landsat/AggieAir reflectance and derived ICI emissivity map.

\section{CONCLUSIONS}

Thermal emissivity is an important property that is necessary for quantification of kinematic or true surface temperature. Microbolometer technology allows for high-resolution thermal mapping from UAVs and airborne sensors, and the captured information can be enhanced by understanding the spectral characteristics of the microbolometer and its effects on the estimation of thermal emissivity. 
This study shows that the spectral response of microbolometer cameras will affect the estimation of kinematic temperatures, due to different emissivity estimates than provided in the literature, and significantly diverge for soil surfaces. Furthermore, the relationship between a microbolometer emissivity (in this case an ICI camera) and reflectance products from Landsat (RGBNIR) is weak, requiring non-linear (i.e. machine learning) approaches for emissivity modeling. The Regression Decision Tree model applied to HYTES ICI derived emissivity and Landsat reflectance was proven to adequately perform for AggieAir high-resolution reflectance information, indicating its suitability for spatial estimation of microbolometer emissivity. While the presented work is an initial approach to estimating emissivity for microbolometer cameras, further work including additional HYTES datasets for different times and locations would refine and improve the accuracy of the estimation of emissivity. In addition, an extended emissivity analysis of microbolometer cameras can be performed by including additional emissivity datasets such as the ASTER spectral library ${ }^{48}$ for manmade surfaces and urban settings as well as more diverse agricultural vegetation. Furthermore, this work has not considered the effect of changes in water content in vegetation (morning dew, sprinklers) nor soil (after irrigation or rainfall), both of which can cause emissivity values to increase with larger water content and decrease with the diurnal cycle ${ }^{49}$.

\section{ACKNOWLEDGEMENT}

This project was supported by USDA-ARS Hydrology and Remote Sensing Laboratory, NNX17AF51G award from NASA, and by the Utah Water Research Laboratory at Utah State University. The authors wish to thank E\&J Gallo Winery for their continued collaborative support of this research, and the AggieAir UAV Remote Sensing Group at the Utah Water Research Laboratory for their UAV technology and their skill and hard work in acquiring the scientific quality, highresolution aerial imagery used in this project. 


\section{REFERENCES}

[1] Kustas, W. P., Alfieri, J. G., Nieto, H., Wilson, T. G., GaO, F. And Anderson, M. C., “Utility of THE TWO-SOURCE ENERGY BALANCE (TSEB) MODEL IN VINE AND INTERROW FLUX PARTITIONING OVER THE GROWING SEASON,” IRRIG. SCI. (2018).

[2] Nieto, H., Bellvert, J., Kustas, W. P., Alfieri, J. G., GaO, F., Prueger, J., Torres-Rua, A. F., HIPPS, L. E., ElARAB, M. AND SONG, L., "UNMANNED AIRBORNE THERMAL AND MULTISPECTRAL IMAGERY FOR ESTIMATING EVAPOTRANSPIRATION IN IRRIGATED VINEYARDS," 2017 IEEE INTERNATIONAL GEOSCIENCE AND REMOTE SENSING SYMPOSIUM (IGARSS), 5510-5513 (2017).

[3] Kilic, A., Allen, R., Trezza, R., Ratcliffe, I., Kamble, B., Robison, C. And OzTurk, D., "SENSITIVITY OF EVAPOTRANSPIRATION RETRIEVALS FROM THE METRIC PROCESSING ALGORITHM TO IMPROVED RADIOMETRIC RESOLUTION OF LANDSAT 8 THERMAL DATA AND TO CALIBRATION BIAS IN LANDSAT 7 AND 8 SURFACE TEMPERATURE," REMOTE SENS. ENVIRON. 185, 198-209 (2016).

[4] Anderson, M. C., Allen, R. G., Morse, A. And Kustas, W. P., "Use Of LANDSAT thermal IMAGERY IN MONITORING EVAPOTRANSPIRATION AND MANAGING WATER RESOURCES," REMOTE SENS. ENVIRON. 122, 50-65 (2012/7).

[5] Liou, Y.-A. AND KAR, S. K., "EVAPOTRANSPIRATION ESTIMATION With REMOTE SENSING AND VARIOUS SURFACE ENERGY BALANCE ALGORITHMS-A REVIEW,” ENERGIES 7(5), 2821-2849 (2014).

[6] Hoffmann, H., Nieto, H., Jensen, R., Guzinski, R., ZARCo-TEJADA, P. AND FriborG, T., "ESTIMATING EVAPORATION WITH THERMAL UAV DATA AND TWO-SOURCE ENERGY BALANCE MODELS,” HYDROL. EARTH SYST. SCI. 20(2), 697-713 (2016).

[7] Carlson, T. N., "ReCEnt AdVANCES In MOdeling the InFrared TEMPERATURE OF Vegetation CANOPIES," [LAND SURFACE EVAPORATION], 349-358 (1991).

[8] Alamdarloo, E. H., Manesh, M. B. And Khosravi, H., "Probability assessment of Vegetation VULNERABILITY TO DROUGHT BASED ON REMOTE SENSING DATA,” ENVIRON. MONIT. ASSESS. 190(12), $702(2018)$.

[9] Roy, D. P., Wulder, M. A., Loveland, T. R., C.E., W., Allen, R. G., Anderson, M. C., Helder, D., Irons, J. R., Johnson, D. M., Kennedy, R., Scambos, T. A., SchaAf, C. B., Schott, J. R., Sheng, Y., Vermote, E. F., Belward, A. S., Bindschadler, R., Cohen, W. B., GaO, F., ET Al., "LANDSAT-8: SCIENCE AND PRODUCT VISION FOR TERRESTRIAL GLOBAL CHANGE RESEARCH," REMOTE SENS. ENVIRON. 145, 154-172 (2014).

[10] Ji, F., Wu, Z., HuANG, J. AND Chassignet, E. P., "EVOlution OF LAND SURFACE AIR TEMPERATURE TREND," NAT. Clim. CHANG. 4(6), 462-466 (2014).

[11] Ho, H. C., ABbas, S., YANG, J., ZhU, R. AND Wong, M. S., "SPATiotemporal Prediction of INCREASING WINTER PERCEIVEd TEMPERATURE ACROSS A SUB-TROPICAL CITY FOR SUSTAINABLE Planning and Climate Change Mitigation," Int. J. EnViron. Res. Public Health 16(3) (2019).

[12] Torres-Rua, A., Nieto, H., Parry, C., Elarab, M., Collatz, W., Coopmans, C., McKee, L., MCKEE, M. AND KUSTAS, W., "INTER-COMPARISON OF THERMAL MEASUREMENTS USING GROUNDBASED SENSORS, UAV THERMAL CAMERAS, AND EDDY COVARIANCE RADIOMETERS," AUTONOMOUS AIR AND GROUND SENSING SYSTEMS FOR AGRICULTURAL OPTIMIZATION AND PHENOTYPING III 10664, 106640E, INTERNATIONAL SOCIETY FOR OPTICS AND PHOTONICS (2018).

[13] TORRES-RUA, A., "VICARIOUS CALIBRATION OF SUAS MiCROBOLOMETER TEMPERATURE IMAGERY FOR ESTIMATION OF RADIOMETRIC LAND SURFACE TEMPERATURE,” SENSORS 17(7) (2017).

[14] Ribeiro-Gomes, K., HernándeZ-LóPez, D., OrTega, J. F., BAllesteros, R., Poblete, T. AND Moreno, M. A., "UnCOOLED THERMAL CAMERA CALIBRATION AND OPTIMIZATION OF THE PHOTOGRAMMETRY PROCESS FOR UAV APPLICATIONS IN AGRICULTURE,” SENSORS 17(10) (2017).

[15] STRAKOWSKI, R. AND WIECEK, B., "TEMPERATURE DRIFT COMPENSATION IN METROLOGICAL MICROBOLOMETER CAMERA USING MULTI SENSOR APPROACH,” PROCEEDINGS OF THE 2016 INTERNATIONAL CONFERENCE ON QUANTITATIVE INFRARED THERMOGRAPHY (2016). 
[16] DE VRIES, J., "IN-SITU CALIBRATION OF A MICROBOLOMETER CAMERA FOR THE STUDY OF LARGE-SCALE FIRES,” THERMOSENSE: THERMAL INFRARED APPLICATIONS XXXV (2013).

[17] KRUPIŃSKI, M., BAREŁA, J., KASTEK, M. AND CHMIELEWSKI, K., “TEST STAND FOR DETERMINING PARAMETERS OF MICROBOLOMETER CAMERA,” ELECTRO-OPTICAL AND INFRARED SYSTEMS: TECHNOLOGY AND APPLICATIONS XIII (2016).

[18] “APOGEE INSTRUMENTS.”, 2010, <HTTP://WWW.APOGEEINSTRUMENTS.COM/INFRAREDRADIOMETER/> (24 FEBRUARY 2017).

[19] "FLIR SYSTEMS.", <HTTP://WWW.FLIR.COM/HOME/> (22 DECEMBER 2016 ).

[20] "THERMAL INFRARED CAMERAS, SERVICE \& SOFTWARE.", <HTTPS://WWW.INFRAREDCAMERAS.COM> (27 FEBRUARY 2019).

[21] Storey, J., ChOATE, M. AND Moe, D., "LANDSAT 8 Thermal InFrared SENSOR GeOMEtriC CHARACTERIZATION AND CALIBRATION,” REMOTE SENSING 6(11), 11153-11181 (2014).

[22] Xiong, X., Chiang, V., Chen, N. AND BARnes, W. L., "AQUA MODIS thermal EMissive BandS CALIBRATION ALGORITHM AND PRELIMINARY RESULTS," EARTH OBSERVING SYSTEMS VII (2002).

[23] Donlon, C., Berruti, B., Buongiorno, A., -H. Ferreira, M., FÉmÉnias, P., Frerick, J., Goryl, P., Klein, U., Laur, H., Mavrocordatos, C., Nieke, J., Rebhan, H., Seitz, B., Stroede, J. ANd SCIARRA, R., "THE GLOBAL MONITORING FOR ENVIRONMENT AND SECURITY (GMES) SENTINEL-3 MISSION," REMOTE SENS. ENVIRON. 120, 37-57 (2012).

[24] Hulley, G., HoOK, S., Fisher, J. AND LeE, C., "ECOSTRESS, A NASA EARTH-Ventures INSTRUMENT FOR STUDYING LINKS BETWEEN THE WATER CYCLE AND PLANT HEALTH OVER THE DIURNAL CYCLE,” 2017 IEEE INTERNATIONAL GEOSCIENCE AND REMOTE SENSING SYMPOSIUM (IGARSS) (2017).

[25] PALlUCONI, F. D., "VALIDATION OF THE ASTER THERMAL INFRARED SURFACE RADIANCE DATA PRODUCT," EARTH OBSERVING SYSTEM (1996).

[26] “9640 P-SERIES | USB CALIBRATED THERMAL CAMERA WITH TEMPERATURE MEASUREMENT | INFRARED CAMERAS INC.", INFRARED CAMERAS INC., <HTTPS://WWW.INFRAREDCAMERAS.COM> $(4$ MARCH 2019 ).

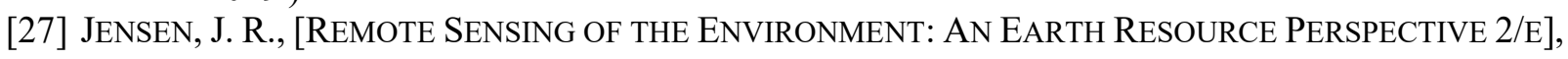
PEARSON EDUCATION INDIA (2009).

[28] Kuznetsov, A., Melnikova, I., Pozdnyakov, D., Seroukhova, O. And Vasilyev, A., [Remote SENSING OF THE ENVIRONMENT AND RADIATION TRANSFER: AN INTRODUCTORY SURVEY], SPRINGER SCIENCE \& BUSINESS MEDIA (2012).

[29] Berni, J. A. J., Zarco-Tejada, P. J., SuArez, L. And Fereres, E., “Thermal and NARrowband MultisPECTRAL REMOTE SENSING FOR VEGETATION MONITORING FROM AN UNMANNED AERIAL VEHICLE," IEEE TRANS. GEOSCI. REMOTE SENS. 47(3), 722-738 (2009).

[30] Tardy, B., Rivalland, V., Huc, M., Hagolle, O., MarcQ, S. And Boulet, G., “A Software ToOl FOR ATMOSPHERIC CORRECTION AND SURFACE TEMPERATURE ESTIMATION OF LANDSAT INFRARED THERMAL DATA,” REMOTE SENSING 8(9), 696 (2016).

[31] ROZENSTEIn, O., QIN, Z., DERIMIAN, Y. AND KARNIELI, A., "DERIVATION OF LAND SURFACE TEMPERATURE FOR LANDSAT-8 TIRS USING A SPLIT WINDOW ALGORITHM,” SENSORS 14(4), 5768-5780 (2014).

[32] BARSi, J. A., BARKER, J. L. AND SCHOtT, J. R., “AN ATMOSPHERIC CORRECTION PARAMETER CALCULATOR FOR A SINGLE THERMAL BAND EARTH-SENSING INSTRUMENT,” IGARSS 2003. 2003 IEEE INTERNATIONAL GEOSCIENCE AND REMOTE SENSING SYMPOSIUM. PROCEEDINGS (IEEE CAT. No.03CH37477) 5, 3014-3016 VOL.5 (2003).

[33] TANG, B.-H., WU, H., LI, C. AND LI, Z.-L., "ESTIMATION OF BROADBAND SURFACE EMISSIVITY FROM NARROWBAND EMISSIVITIES,” OPT. EXPRESS 19(1), 185-192 (2011). 
[34] Hulley, G. C. AND HoOK, S. J., “Generating Consistent LAND SuRface TeMPERATURE AND EMISSIVITY PRODUCTS BETWEEN ASTER AND MODIS DATA FOR EARTH SCIENCE RESEARCH,” IEEE TRANS. GEOSCI. REMOTE SENS. 49(4), 1304-1315 (2011).

[35] Hulley, G. C., Hook, S. J., AbBott, E., Malakar, N., Islam, T. AND Abrams, M., “The ASTER GLOBAL EMISSIVITY DATASET (ASTER GED): MAPPING EARTH'S EMISSIVITY AT 100 METER SPATIAL SCALE: ASTER EMISSIVITY DATASET,” GEOPHYS. RES. LETT. 42(19), 7966-7976 (2015).

[36] BENIRSCHKE, D. AND HOWARD, S., "CHARACTERIZATION OF A LOW-COST, COMMERCIALLY AVAILABLE, VANADIUM OXIDE MICROBOLOMETER ARRAY FOR SPECTROSCOPIC IMAGING," OPTICAL ENGINEERING 56(4), 040502 (2017).

[37] WAN, Z. M. AND ZHANG, Y., "MODIS UCSB EMISSIVITY LIBRARY,” MODIS UCSB EMISSIVITY LIBRARY (1999).

[38] Kustas, W. P., Anderson, M. C., Alfieri, J. G., KnipPer, K., Torres-Rua, A., Parry, C. K., Nieto, H., Agam, N., White, W. A., GaO, F., McKee, L., Prueger, J. H., Hipps, L. E., Los, S., Alsina, M. M., SANCHEZ, L., SAMS, B., DokOOZlian, N., MCKeE, M., ET AL., "THE GRAPE REMOTE SENSING ATMOSPHERIC PROFILE AND EVAPOTRANSPIRATION EXPERIMENT (GRAPEX),” BULL. AM. METEOROL. SOC. 99(9), 1791-1812 (2018).

[39] HOOK, S. J., JOHNSON, W. R. AND ABRAMS, M. J., “NASA's HYPERSPECTRAL THERMAL EMISSION SPECTROMETER (HYTES)," [THERMAL INFRARED REMOTE SENSING: SENSORS, METHODS, APPLICATIONS], C. KUENZER AND S. DECH, EDS., SPRINGER NETHERLANDS, DORDRECHT, 93-115 (2013).

[40] Johnson, W. R., Hook, S. J., Mouroulis, P., Wilson, D. W., Gunapala, S. D., Realmuto, V., LAMBORN, A., PAINe, C., MuMOlO, J. M. AND ENG, B. T., "HYTES: THERMAl IMAGing SPECTROMETER DEVELOPMENT," 2011 AEROSPACE CONFERENCE, 1-8 (2011).

[41] Gillespie, A., Rokugawa, S., Matsunaga, T., Cothern, J. S., Hook, S. And Kahle, A. B., “A TEMPERATURE AND EMISSIVITY SEPARATION ALGORITHM FOR ADVANCED SPACEBORNE THERMAL EMISSION AND REFLECTION RADIOMETER (ASTER) IMAGES," IEEE TRANSACTIONS ON GEOSCIENCE AND REMOTE SENSING 36(4), 1113-1126 (1998).

[42] Seemann, S. W., Borbas, E. E., Knuteson, R. O., Stephenson, G. R. And Huang, H.-L., "DEVELOPMENT OF A GLOBAL INFRARED LAND SURFACE EMISSIVITY DATABASE FOR APPLICATION TO

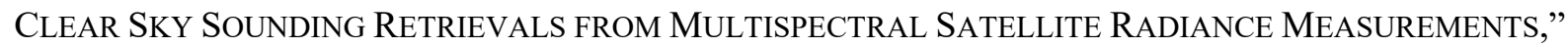
JOURNAL OF APPLIED METEOROLOGY AND CLIMATOLOGY 47(1), 108-123 (2008).

[43] "HYPERSPECTRAL THERMAL EMISSION SPECTROMETER.”, < HTTPS://HYTES.JPL.NASA.GOV/> (4 MARCH 2019 ).

[44] “LANDSAT SURFACE REFLECTANCE.”, < HTTPS://WWW.USGS.GOV/LANDRESOURCES/NLI/LANDSAT/LANDSAT-SURFACE-REFLECTANCE> (1 MARCH 2019$)$.

[45] Mahyar Aboutalebi, Alfonso Torres-Rua, Mac McKee, Hector Nieto, William Kustas, JoHn PRUEGER, LYNN MCKEE, JOSEPH ALFIERI, LAWRENCE HIPPS, CALVIN COOPMANS., “ASSESSMENT OF LANDSAT HARMONIZED SUAS REFLECTANCE PRODUCTS USING POINT SPREAD FUNCTION (PSF) ON VEGETATION INDICES (VIS) AND EVAPOTRANSPIRATION (ET) USING THE TWO-SOURCE ENERGY BALANCE (TSEB) MODEL" (2018).

[46] Hulley, G., Malakar, N., Hughes, T., Islam, T. AND Hook, S., "Moderate Resolution Imaging SPECTRORADIOMETER (MODIS) MOD21 LAND SURFACE TEMPERATURE AND EMISSIVITY ALGORITHM THEORETICAL BASIS DOCUMENT," JPL PUBLICATION 12-17, REV. 2, JET PROPULSION LABORATORY, NATIONAL AERONAUTICS AND SPACE AdMINISTRATION (2016).

[47] Breiman, L., Friedman, J., Stone, C. J. AND Olshen, R. A., [Classification AND Regression TREES], CRC PRESS (1984).

[48] Baldridge, A. M., HoOK, S. J., Grove, C. I. AND Rivera, G., “The ASTER SPECTRAL Library VERSION 2.0,” REMOTE SENS. ENVIRON. 113(4), 711-715 (2009). 
[49] Mira, M., Valor, E., Caselles, V., Rubio, E., Coll, C., Galve, J. M., Niclos, R., Sanchez, J. M. AND BOLUDA, R., "SOIL MOISTURE EFFECT ON THERMAL INFRARED (8-13-MM) EMISSIVITY," IEEE TRANS. GEOSCI. REMOTE SENS. 48(5), 2251-2260 (2010).

Proc. of SPIE Vol. 11008 1100802-20

Downloaded From: https://www.spiedigitallibrary.org/conference-proceedings-of-spie on 13 Aug 2019 Terms of Use: https://www.spiedigitallibrary.org/terms-of-use 